\title{
Tanggung Jawab Notaris Dalam Menjaga Keamanan Digitalisasi Akta
}

\section{Regina Natalie Theixar ${ }^{1}$,Ni Ketut Supasti Dharmawan ${ }^{2}$}

1Fakultas Hukum Universitas Udayana, E-mail: reginatheixar@gmail.com

2Fakultas Hukum Universitas Udayana, E-mail: supasti_dharmawan@unud.ac.id

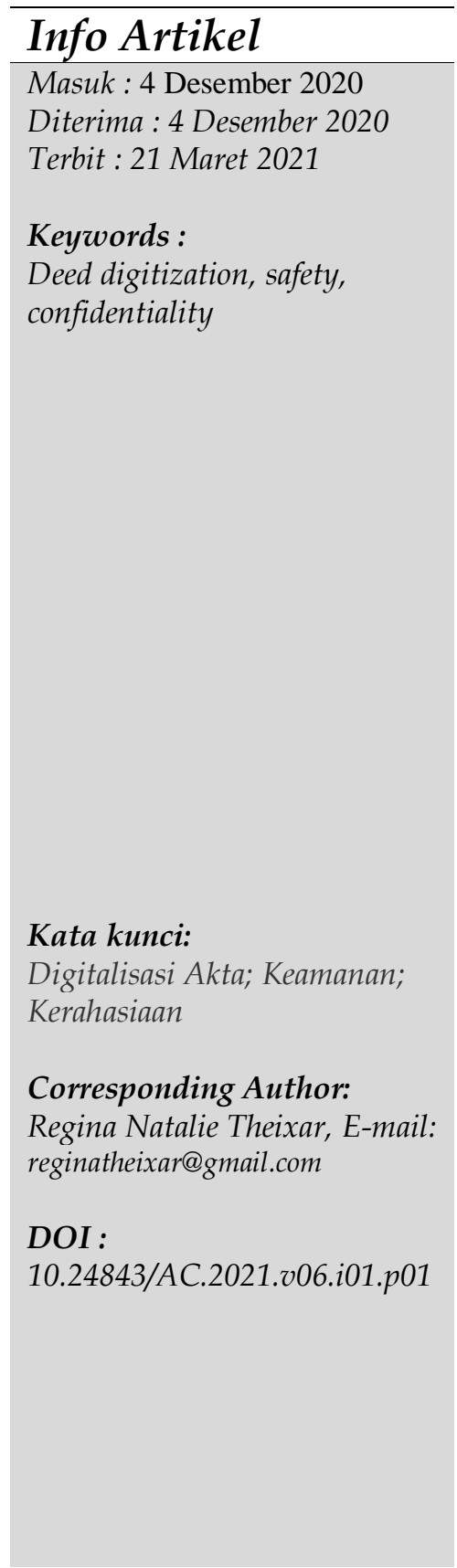

\begin{abstract}
The purpose of this research is to examine notary's roles and responsibilities regarding data security of the parties. This study uses normative legal research methods. The results of this study indicate that the misuse of digital signatures can be avoided by taking preventive measures, such as increasing the security of computer device securities in accordance with the UN Congress Resolution policy standards as outlined in the Information and Electronic Transaction Law and Government Regulations on the Implementation of Electronic Systems and Transactions, one of which is the use of digital signature based on digital certificate. However, if the notary fails to maintain the security and data confidentiality of the parties in the deed that they make and keep, it can be related to neglecting to carry out the Notary's obligations in article 16 letter ( $f)$, to keep everything about the Deed made by the Notary confidential. Administrative sanctions for notary negligence include written warnings, temporary dismissal, honorific dismissal, or dishonorable dismissal. If the Notary is proven to have deliberately manipulated or caused the loss or damage of the deed so that it fulfills the elements of an illegal act based on Article 1365 of the Civil Code, civil and criminal sanctions may be imposed.
\end{abstract}

\footnotetext{
Abstrak

Tujuan penelitian ini yaitu untuk mengkaji peran dan tanggung jawab notaris berkaitan dengan keamanan data para pihak. Studi ini menggunakan metode penelitian hukum normatif. Hasil penelitian ini mengunjukkan bahwa penyalahgunaan tanda tangan digital dapat dihindari dengan tindakan preventif yakni meningkatkan keamanan sekuritas perangkat komputer sesuai dengan standar kebijakan Resolusi Kongres PBB yang dituangkan dalam Undang-Undang Informasi dan Transaksi Elektronik serta Peraturan Pemerintah Penyelenggaraan Sistem dan Transaksi Elektronik, salah satunya dengan penggunaan digital signature berdasarkan digital certificate. Namun apabila notaris gagal menjaga keamanan dan kerahasiaan data para pihak dalam akta yang dibuat dan disimpannya, dapat dikaitkan dengan lalai menjalankan kewajiban Notaris dalam pasal 16 huruf (f) yakni merahasiakan segala sesuatu mengenai Akta yang dibuat Notaris. Sanksi administratif atas kelalaian notaris berupa peringatan tertulis, pemberhentian sementara,
} 
pemberhentian dengan hormat, atau pemberhentian dengan tidak hormat. Apabila Notaris terbukti dengan sengaja memanipulasi atau menyebabkan hilang maupun rusaknya akta sehingga memenuhi unsur perbuatan melawan hukum berdasarkan Pasal 1365 Kitab Undang-Undang Hukum Perdata, dapat dikenakan sanksi perdata dan pidana.

\section{Pendahuluan}

Pesatnya perkembangan informasi dan teknologi elektronik telah merubah berbagai aspek kehidupan manusia yang secara langsung menyebabkan lahirnya perubahan hukum. Produk hukum yang dihasilkan berkembang seiring kemajuan teknologi karena kebutuhan untuk mengisi kekosongan hukum. Notaris di era revolusi industri tidak luput dari cyber notary yang diharapkan dapat menawarkan kemudahan dalam menjalankan tugas dan fungsi pejabat pembuat akta autentik. Selama ini konsepsi cyber notary dapat diartikan sebagai notaris yang melaksanakan tugas, fungsi dan kewenangannya dengan menggunakan teknologi informasi terutama dalam membuat akta. ${ }^{1}$

Pasal 1868 Kitab Undang-Undang Hukum Perdata (selanjutnya disebut KUHPer) mengatur bahwa: "Suatu akta otentik ialah suatu akta yang dibuat dalam bentuk yang ditentukan undang-undang oleh atau di hadapan pejabat umum yang berwenang untuk itu di tempat akta itu dibuat." Pasal ini menurut interpretasi penulis, memberikan pembatasan secara implisit terhadap kemungkinan dilakukannya digitalisasi akta, yakni para pihak hadir di hadapan dan bersamasama dengan notaris, para pihak membaca draft akta di komputer atau gadget dan menandatangani akta secara elektronik. Setelah penandatanganan akta, notaris wajib menyimpan minuta akta yang merupakan bagian dari Protokol Notaris yang diatur dalam Pasal 16 ayat (1) huruf b Undang-Undang Nomor 2 Tahun 2014 Tentang Perubahan Atas Undang-Undang Nomor 30 Tahun 2004 Tentang Jabatan Notaris (selanjutnya akan disebut UUJN-P): "membuat Akta dalam bentuk Minuta Akta dan menyimpannya sebagai bagian dari Protokol Notaris". Pengecualian mengenai kewajiban menyimpan akta diatur dalam Pasal 16 ayat (2) UUJN-P: "Kewajiban menyimpan Minuta Akta sebagaimana dimaksud pada ayat (1) huruf b tidak berlaku, dalam hal Notaris mengeluarkan Akta in originali."

Minuta akta adalah asli dari akta Notaris yang berisi tanda tangan para penghadap, saksi-saksi, dan Notaris, yang kemudian disimpan oleh Notaris sebagai bagian dari Protokol. Jika Notaris menerapkan digitalisasi akta, maka Notaris akan menyimpan data-data personal klien di dalam komputer Notaris ataupun pegawai Notaris, seperti identitas sesuai Kartu Tanda Penduduk, perbuatan hukum yang dilakukan klien dan tanda tangan digital klien. Notaris dalam melaksanakan tugas dan fungsinya, wajib merahasiakan segala hal yang memiliki kaitan dengan akta yang dibuat oleh notaris yang bersangkutan dan

1 Putri, C. C., Yahanan, A., \& Trisaka, A. (2019). Penyimpanan Protokol Notaris Secara Elektronik dalam Konsep Cyber Notary (Doctoral dissertation, Sriwijaya University), h.3-4. 
segala informasi yang diperoleh sehingga akta tersebut sesuai dengan sumpah jabatan notaris, kecuali undang-undang mengatur lain (Pasal 16 ayat (1) huruf $f$ UUJN-P). ${ }^{2}$

Teknologi informasi selain bermanfaat bagi kehidupan, juga berdampak pada munculnya berbagai masalah dalam ruang lingkup hukum. Kondisi ketertinggalan perkembangan hukum di Indonesia disebabkan oleh sejumlah regulasi yang masih merupakan produk warisan penjajahan yang maupun produk hukum yang dibuat di masa sekarang ini dari sisi substansi belum mampu untuk mengimbangi perkembangan pesat teknologi informasi. ${ }^{3}$ Problematika yang dihadapi notaris pada era digital ini adalah menjaga keamanan penyimpanan data para penghadap dari gangguan digital seperti komputer terinfeksi virus, pencurian data, modifikasi data serta penyalahgunaan tanda tangan elektronik. Penelitian dengan objek serupa pernah dilakukan oleh Desy Rositawati pada tahun 2017 dalam Jurnal Acta Comitas yang berjudul Penyimpanan Protokol Notaris Secara Elektronik dalam Kaitan Cyber Notary, membahas mengenai urgensi penyimpanan protokol notaris secara elektronik, mekanisme dan kekuatan pembuktiannya. ${ }^{4}$ Namun dengan diundangkannya Peraturan Pemerintah Nomor 71 Tahun 2019 tentang Penyelenggaraan Sistem dan Transaksi Elektronik (selanjutnya disebut PP PSTE) yang ditujukan untuk menanggulangi permasalahan penyalahgunaan data pribadi masyarakat dan kebocoran kerahasiaan data, peraturan ini diharapkan mendukung pelaksanaan praktik cyber notary dan mengisi kekosongan hukum dalam praktik cyber notary. Sehingga fokus penelitian ini adalah digitalisasi akta dalam kaitannya dengan cyber notary pasca diundangkannya PP PSTE. Permasalahan yang akan dikaji adalah apa peran notaris dalam menjaga keamanan akta yang disimpan dalam bentuk digital dan bagaimana tanggung jawab notaris terhadap keamanan akta digital serta apabila terjadi penyalahgunaan data pribadi klien atas gangguan digital. Penelitian ini bertujuan untuk memperjelas batas-batas dan peran notaris dalam penerapan cyber notary terutama dalam menjaga keamanan data para pihak pasca diundangkannya PP PSTE serta bentuk pertanggungjawaban notaris berdasarkan peraturan perundang-undangan yang berkaitan.

Berdasarkan latar belakang permasalahan tersebut diatas, penulis akan mengkaji analisa yang berjudul "Tanggung Jawab Notaris Dalam Menjaga Keamanan Digitalisasi Akta".

2 Arifaid, P. (2017). TanggungJawab Hukum Notaris Terhadap Akta In Originali. Jurnal IUS Kajian Hukum dan Keadilan, 5(3), 510-520, h.511-514.

${ }^{3}$ Nurita, R.A.E. (2012). Cyber Notary Pemahaman Awal Dalam Konsep Pemikiran. Bandung: Refika Aditama. h.5.

${ }^{4}$ Rositawati, D., Utama, I. M. A., \& Kasih, D. P. D. (2017). Penyimpanan Protokol Notaris secara Elektronik dalam Kaitan Cyber Notary. Acta Comitas: Jurnal Hukum Kenotariatan, 2(2), 172-182, h.173. 


\section{Metode Penelitian}

Jurnal ilmiah ini menggunakan metode penelitian normatif dengan fokus kajian kekaburan norma. Penelitian ini menggunakan pendekatan perundang-undangan (the statute approach) dan pendekatan analisis (analytical approach). Bahan hukum terdiri dari bahan hukum primer berupa peraturan perundang-undangan, bahan hukum sekunder berupa buku, jurnal dan penelitian hukum, serta gagasan atau pandangan dari para ahli, bahan hukum tertier yang bersumber dari kamus hukum ensiklopedia hukum. Pada penelitian hukum normatif ini, teknik analisis bahan hukum yang digunakan oleh penulis adalah teknik deskripsi dan teknik interpretasi. Teknik deskripsi dilakukan dengan menguraikan kenyataan atau kondisi dari berbagai fakta hukum maupun fakta non hukum. Teknik interpretasi adalah melakukan penafsiran dalam ilmu hukum yang terdiri dari penafsiran gramatikal, sistematis, dan teologis.

\section{Hasil Dan Pembahasan}

\subsection{Peran Notaris Dalam Menjaga Keamanan Akta Yang Disimpan Dalam Bentuk Digital}

Notaris merupakan pejabat umum yang berwewenang untuk membuat akta autentik dan beberapa wewenang lainnya yang diatur dalam UUJN, UUJN-P dan peraturan perundang-undangan lainnya. Akta Notaris merupakan akta autentik sesuai dengan hukum positif yang digarap oleh notaris dan di hadapan notaris karena selain diwajibkan demikian undang-undang, juga merupakan kehendak para pihak yang memiliki kepentingan dalam rangka menjamin hak dan kewajiban pihak-pihak, agar tercipta kepastian, keharmonisan dan perlindungan hukum bagi para pihak yang memiliki kepentingan dan bagi masyarakat secara umum. ${ }^{5}$

Struktur akta autentik berdasarkan Pasal 38 UUJN-P:

"(1) Setiap Akta terdiri atas:

a. awal Akta atau kepala Akta;

b. badan Akta; dan

c. akhir atau penutup Akta.

(2) Awal Akta atau kepala Akta memuat:

a. judul Akta;

b. nomor Akta;

c. jam, hari, tanggal, bulan, dan tahun; dan

d. nama lengkap dan tempat kedudukan Notaris.

(3) Badan Akta memuat:

a. nama lengkap, tempat dan tanggal lahir, kewarganegaraan, pekerjaan, jabatan, kedudukan, tempat tinggal para penghadap dan/atau orang yang mereka wakili;

b. keterangan mengenai kedudukan bertindak penghadap;

${ }^{5}$ Fitriyeni, C. E. (2012). Tanggung Jawab Notaris Terhadap Penyimpanan Minuta Akta Sebagai Bagian Dari Protokol Notaris. KANUN: Jurnal Ilmu Hukum, 14(3), 391-404, h.391. 
c. isi Akta yang merupakan kehendak dan keinginan dari pihak yang berkepentingan; dan

d. nama lengkap, tempat dan tanggal lahir, serta pekerjaan, jabatan, kedudukan, dan tempat tinggal dari tiap-tiap saksi pengenal.

(4) Akhir atau penutup Akta memuat:

a. uraian tentang pembacaan Akta sebagaimana dimaksud dalam Pasal 16 ayat (1) huruf $m$ atau Pasal 16 ayat (7);

b. uraian tentang penandatanganan dan tempat penandatanganan atau penerjemahan Akta jika ada;

c. nama lengkap, tempat dan tanggal lahir, pekerjaan, jabatan, kedudukan, dan tempat tinggal dari tiap-tiap saksi Akta; dan

d. uraian tentang tidak adanya perubahan yang terjadi dalam pembuatan Akta atau uraian tentang adanya perubahan yang dapat berupa penambahan, pencoretan, atau penggantian serta jumlah perubahannya."

Akta dengan struktur sebagaimana tersebut di atas, terlebih dahulu dibuatkan draf pada komputer seiring dengan perkembangan zaman. Sebelum perkembangan teknologi komputer berkembang seperti sekarang ini, Notaris atau pegawai Notaris mengetik secara manual akta yang dibuatnya dengan menggunakan mesin ketik. Kini, pembuatan akta dipermudah dengan teknologi komputer yang mampu menyimpan data berupa draf akta. Kamus Besar Bahasa Indonesia mendefinisikan draf sebagai rancangan atau konsep (surat dan sebagainya). Jika dikaji secara historis, dulunya pembuatan akta autentik masih dilakukan dengan tulisan tangan, kemudian digantikan oleh Mesin TIK, yakni mesin penyusun huruf, yang pada saat itu dianggap lebih praktis dan mudah dibaca karena bentuk dan susunan hurufnya lebih konsisten. Notaris pun menyimpan aktanya hanya dalam bentuk minuta fisik yang ditulis atau diketik. Pasal 1 angka 8 UUJN-P berbunyi: "Minuta adalah asli Akta yang mencantumkan tanda tangan para penghadap, saksi, dan Notaris, yang disimpan sebagai bagian dari Protokol Notaris."

Berbeda dengan keadaan saat ini, teknologi yang berkembang pesat menyebabkan berbagai profesi, salah satunya yaitu Notaris, beralih menggunakan komputer atau laptop untuk merancang dan membuat akta. Pembuatan akta dengan menggunakan komputer dinilai lebih praktis dengan berbagai alasan sebagai berikut: (1) apabila terjadi kesalahan ketikan dalam akta, dapat dihapus dan diperbaiki sebelum dicetak; (2) menghemat waktu karena adanya draf akta dengan bentuk baku; (3) apabila terjadi perubahan keinginan kehendak para pihak tepat sebelum penandatanganan akta, dapat diperbaiki dengan segera; (4) meminimalisir jumlah renvoi; dan berbagai alasan efisiensi lainnya. Notaris dan pegawai notaris kini membuat dan menyimpan draf akta secara digital, kemudian dicetak lalu ditandatangani oleh para pihak.

Hingga saat ini, pelaksanaan kewenangan notaris secara cyber notary yang didukung oleh peraturan perundang-undangan adalah melakukan sertifikasi transaksi elektronik sebagaimana diatur dalam penjelasan Pasal 15 ayat (3) UUJN- 
P dan pembuatan akta relaas pada Rapat Umum Pemegang Saham Perseroan Terbatas yang dilaksanakan melalui media telekonferensi atau pertemuan langsung berbasis elektronik, video konferensi atau berbagai sarana media elektronik lain yang diatur dalam Pasal 77 Undang-Undang Nomor 40 Tahun 2007 tentang Perseroan Terbatas. Perkembangan ini tentunya tidak berhenti hanya sampai disini saja. Kedepannya, ada beberapa kemungkinan dilakukan perubahan kedua terhadap UUJN ataupun dibentuknya undang-undang baru yang memfasilitasi Notaris untuk menyimpan minuta akta dalam bentuk digital ataupun berbagai kemajuan yang membuat pekerjaan Notaris lebih efisien dan praktis.

Berbagai hal positif yang ditawarkan oleh kecanggihan komputer tentunya juga memiliki hal negatif, salah satunya yaitu gangguan digital berupa virus dalam komputer. Virus berdasarkan KBBI adalah program ilegal yang masuk ke dalam sistem komputer melalui jaringan hingga menyebar dan berpotensi merusak program dalam komputer. Gangguan digital yang disebabkan oleh virus, implikasinya terhadap perusakan berkas digital atau data yang terdapat dalam berkas tersebut, bahkan bisa saja hilang. Dalam hal belum adanya kebijakan penyimpanan minuta akta secara digital, maka hal ini akan berdampak terhadap draf akta yang telah dirancang. Peran notaris secara preventif yaitu memasang anti-virus pada seluruh perangkat yang digunakan untuk merancang akta, serta lebih teliti dan membacakan akta sebelum penandatanganan akta yang merupakan kewajiban Notaris sebagaimana diatur dalam Pasal 16 huruf m UUJNP.

Sedangkan gangguan digital yang lebih berbahaya yaitu peretasan (hack) perangkat komputer. Peretasan adalah kegiatan memodifikasi, masuk dengan paksaan atau menerobos ke dalam komputer dan jaringan komputer, dalam rangka mencari keuntungan bagi seseorang maupun kelompok. Peretasan perangkat komputer Notaris yang memuat draf akta dapat menyebabkan hal sebagai berikut:

1. penyalahgunaan informasi pribadi para pihak maupun objek perjanjian;

2. kerahasiaan akta notaris dilanggar;

3. manipulasi data yang merugikan para pihak dan Notaris.

Pengaturan mengenai peretasan diatur dalam Undang-Undang Nomor 11 Tahun 2008 tentang Informasi dan Transaksi Elektronik (selanjutnya disebut UU ITE). Peretasan didefinisikan sebagai tindakan kriminal di bidang kejahatan dunia maya. Pasal 30 UU ITE mengatur mengenai kualifikasi peretas yang dapat dijerat hukum pidana, berbunyi:

“(1) Setiap Orang dengan sengaja dan tanpa hak atau melawan hukum mengakses Komputer dan/atau Sistem Elektronik milik Orang lain dengan cara apa pun.

(2) Setiap Orang dengan sengaja dan tanpa hak atau melawan hukum mengakses Komputer dan/atau Sistem Elektronik dengan cara apa pun dengan tujuan untuk memperoleh Informasi Elektronik dan/atau Dokumen Elektronik. 
(3) Setiap Orang dengan sengaja dan tanpa hak atau melawan hukum mengakses Komputer dan/atau Sistem Elektronik dengan cara apa pun dengan melanggar, menerobos, melampaui, atau menjebol sistem pengamanan."

Ancaman terhadap pelanggaran di atas dimuat dalam Pasal 46 UU ITE:

“(1) Setiap Orang yang memenuhi unsur sebagaimana dimaksud dalam Pasal 30 ayat (1) dipidana dengan pidana penjara paling lama 6 (enam) tahun dan/atau denda paling banyak Rp600.000.000,00 (enam ratus juta rupiah).

(2) Setiap Orang yang memenuhi unsur sebagaimana dimaksud dalam Pasal 30 ayat (2) dipidana dengan pidana penjara paling lama 7 (tujuh) tahun dan/atau denda paling banyak Rp700.000.000,00 (tujuh ratus juta rupiah).

(3) Setiap Orang yang memenuhi unsur sebagaimana dimaksud dalam Pasal 30 ayat (3) dipidana dengan pidana penjara paling lama 8 (delapan) tahun dan/atau denda paling banyak Rp800.000.000,00 (delapan ratus juta rupiah)."

Upaya penanggulangan kejahatan dunia maya, Resolusi Kongres Perserikatan Bangsa-Bangsa Nomor VIII/1990 mengenai kejahatan komputer mengajukan beberapa kebijakan yang diterjemahkan dan dirangkum oleh Barda Nawawi Arief sebagai berikut 6 :

“a) Mengimbau negara anggota untuk mengintensifkan upaya-upaya penanggulangan penyalahgunaan komputer yang lebih efektif dengan mempertimbangkan langkah-langkah di antaranya:

1) Melakukan modernisasi hukum pidana material dan hukum acara pidana;

2) Mengembangkan tindakan-tindakan pencegahan dan pengamanan komputer;

3) Melakukan langkah-langkah untuk membuat peka (sensistif) warga masyarakat, aparat pengadilan, dan penegak hukum, terhadap pentingnya pencegahan kejahatan yang berhubungan dengan komputer (Cyber crime);

4) Melakukan upaya pelatihan bagi para hakim, pejabat, dan aparat penegak hukum mengenai kejahatan ekonomi dan cyber crime;

5) Memperluas rules of ethics (aturan dan etika) dalam penggunaan komputer dan mengajarkannya melalui kurikulum informatika;

6) Mengadopsi kebijakan perlindungan korban cyber crime sesuai dengan deklarasi Perserikatan Bangsa-Bangsa mengenai korban, dan mengambil langkah-langkah untuk mendorong korban melaporkan adanya cyber crime.

b) Mengimbau negara anggota meningkatkan kegiatan internasional dalam upaya penanggulan cyber crime;

c) Merekomendasikan kepada Komite Pengendalian dan Pencegahan Kejahatan (committee on Crime Prevention and Control) PBB untuk:

1) Menyebarluaskan pedoman dan standar untuk membantu negara anggota menghadapi cyber crime di tingkat nasional, regional, dan internasional;

2) Mengembangkan penelitian dan analisis lebih lanjut guna menemukan cara-cara baru menghadapi problem cyber crime di masa yang akan datang;

${ }^{6}$ Arief, B. N. (2018). Masalah Penegakan Hukum dan Kebijakan Hukum Pidana dalam Penanggulangan Kejahatan. Jakarta: Prenada Media, h.246-247 dikutip dari United Nations, 1991, Eighth UN Congress on the Prevention of Crime and the Treatment of Offenders, Report, p.141-142. 
3) Mempertimbangkan cyber crime sewaktu meninjau pengimplementasian perjanjian ekstradisi dan bantuan kerja sama di bidang penanggulangan kejahatan."

Beberapa sarjana menilai panduan kebijakan untuk menangani kejahatan dunia maya yang dimuat dalam resolusi PBB komprehensif. Penanggulangan terdiri dari kebijakan penal maupun non-penal. Kebijakan penal adalah hukum pidana materiil dan hukum pidana formal. Kebijakan non-penal yang diajukan dalam resolusi PBB sangat menarik karena merupakan hal yang sudah sepatutnya dilakukan namun kadang maish disepelekan yakni upaya mengembangkan keamanan dan langkah-langkah preventif. Hal tersebut berkaitan dengan metode pencegahan teknis, yaitu penggunaan teknologi untuk mencegah dan mengendalikan kejahatan. ${ }^{7}$

Peran Notaris dalam hal peretasan terhadap perangkat komputernya harus dimulai dari tindakan preventif, seperti meningkatkan keamanan sekuritas perangkat komputer sebagaimana standar kebijakan Resolusi Kongres PBB diatas yang telah dituangkan dalam UU ITE dan peraturan pelaksananya.

Pemerintah juga turut serta berperan dalam melindungi kepentingan publik dari segala macam gangguan yang mengganggu ketertiban umum yang diakibatkan oleh penyalahgunaan ITE, serta mencegah penyebaran maupun penggunaan ilegal informasi, data dan dokumen elektronik yang isinya dilarang oleh peraturan perundang-undangan dengan diundangkannya PeraturanPemerintah Nomor 71 Tahun 2019 tentang Penyelenggaraan Sistem dan Transaksi Elektronik dan dengan dicabutnya PeraturanPemerintah Nomor 82 Tahun 2012 tentang Penyelenggaraan Sistem dan Transaksi Elektronik. Peran pemerintah dalam perlindungan gangguan digital ini berkaitan dengan Teori Perlindungan Hukum yang didefinisikan oleh Philipus M. Hadjon sebagai perlindungan akan harkat dan martabat, serta pengakuan terhadap hak asasi manusia yang dimiliki subjek hukum. Kebebasan dilindungi hukum merupakan hak asasi manusia, termasuk perlindungan dari penyalahgunaan data-data pribadi yang berkaitan dengan ITE.

Berkaitan dengan tanda tangan digital atau digital signature, penggunaannya terdiri dari dua proses sebagai berikut ${ }^{8}$ :

1) Pembuatan tanda tangan digital dengan menggunakan kode dari hasil enkripsi yang disebut nilai hash dan kunci privat. Tanda tangan digital memiliki keunikan dan perbedaan masing-masing layaknya sidik jari manusia, kemungkinan untuk adanya digital signature yang sama sangat kecil.

\footnotetext{
7 Utami, M. N. (2019). Kejahatan Peretasan (Hacking) dan Pemerasan 3000 Website di 44 Negara Oleh Surabaya Black Hat Dihubungkan Dengan UU No 19 Tahun 2016 Tentang Informasi Teknologi Dan Elektronik (ITE). Skripsi Fakultas Hukum Universitas Pasundan Bandung, h.50.

${ }^{8}$ Hudzaifah, H. (2015). Keabsahan Tanda Tangan Elektronik Dalam Pembuktian Hukum Acara Perdata Indonesia. Katalogis, 3(5), h.196.
} 
2) Verifikasi proses pemeriksaan digital signature dengan referensi dari dokumen asli ke kunci publik, sehingga dipastikan apabila digital signature tersebut memang diciptakan untuk dokumen yang dimaksud dengan menggunakan kunci privat.

Keabsahan digital signature diatur oleh Pasal 11 Undang-Undang ITE mensyaratkan:

“1) Data pembuatan digital signature hanya terkait dengan penandatangan

2) Data pembuatan digital signature pada saat proses penandatanganan hanya berada dalam kuasa penandatangan;

3) Setiap perubahan terhadap digital signature yang terjadi setelah penandatanganan dapat diketahui;

4) Setiap perubahan terhadap informasi elektronik yang terkait dengan digital signature dapat diketahui;

5) Harus ada cara untuk mengidentifikasi penandatangan;

6) Harus ada cara untuk membuktikan bahwa penandatangan telah setuju terhadap informasi elektronik yang berkaitan dengan digital signature."

UU ITE secara eksplisit mengakui bahwa digital signature memiliki kedudukan hukum dan kekuatan hukum yang setara dengan tanda tangan dengan cara konvensional selama telah terpenuhi syarat-syarat yang diatur dalam UU ITE Pasal 11. PP PSTE mendukung penjelasan lebih lanjut dari UU ITE, yang selanjutnya hanya diperlukan pengaturan lebih lanjut mengenai cyber notary mengenai digitalisasi akta sehingga dapat bersinergi dengan PP PSTE. ${ }^{9}$

PP PSTE tidak memuat aturan spesifik mengenai cyber notary, hanya menjelaskan lebih lanjut mengenai penggunaan tanda tangan elektronik yang dapat dikaitkan dengan penerapan cyber notary dalam penandatanganan akta. Dalam praktik, penggunaan tanda tangan elektronik oleh notaris belum dimungkinkan dalam penandatanganan akta partij karena kewajiban notaris untuk membacakan akta di hadapan para pihak. Sedangkan penggunaan tanda tangan elektronik dalam akta relaas seperti pada Rapat Umum Pemegang Saham yang dilaksanakan dengan video konferensi masih dimungkinkan karena notaris hadir dan terlibat dalam RUPS tersebut secara langsung.

\subsection{Tanggung Jawab Notaris Terhadap Keamanan Akta Digital}

Notaris adalah pejabat umum yang berkuasa menjalankan sebagian dari kekuasaan negara, terutama dalam hukum perjanjian. Notaris merupakan suatu profesi, tetapi juga merupakan suatu jabatan. Sebagai seorang pejabat umum, tanggung jawab notaris jika dikaji dengan Teori Kekuasaan Negara, yaitu memberikan pelayanan berupa dokumen autentik dalam bidang hukum perdata.

\footnotetext{
${ }^{9}$ Juana, I. K. W. (2019). KEKUATAN HUKUM TANDA TANGAN DIGITAL DALAM PEMBUKTIAN SENGKETA PERDATA MENURUT UNDANG-UNDANG NOMOR 11 TAHUN 2008 TENTANG INFORMASI DAN TRANSAKSI ELEKTRONIK. Kerta Dyatmika, 16(1), 62-70, h.68.
} 
Kewenangan untuk melakukan hal tersebut diberikan kepada notaris, sehingga notaris harus menyimpan arsip negara sebagai protokol dalam bentuk minuta akta, yang diakui oleh negara karena memiliki kekuatan pembuktian yang sempurna demi tercapainya kepastian hukum.

Tanggung jawab notaris terhadap keamanan akta digital ini dibatasi pada hilang atau kerusakan protokol yang disimpan secara elektronik oleh Notaris serta menjaga kerahasiaan akta ${ }^{10}$. Pasal 16 huruf b UUJN-P menentukan hal yang wajib Notaris lakukan yakni membuat akta autentik berbentuk minuta dan menyimpan akta tersebut sebagai bagian dari protokol Notaris. Apabila hilang atau rusaknya minuta akta disebabkan karena kesengajaan Notaris yang menimbulkan kerugian bagi para pihak dan menyebabkan tidak adanya kepastian hukum, maka hal tersebut merupakan pelanggaran. Pasal 16 huruf f UUJN-P menentukan bahwa Notaris wajib: "merahasiakan segala sesuatu mengenai Akta yang dibuatnya dan segala keterangan yang diperoleh guna pembuatan Akta sesuai dengan sumpah/janji jabatan, kecuali undang-undang menentukan lain". Pelanggaran terhadap Pasal 16 huruf $\mathrm{b}$ dan huruf $\mathrm{f}$ UUJN-P dapat dikenakan sanksi sebagaimana diatur dalam Pasal 75 UUJN, berupa teguran lisan, tertulis, pemberhentian sementara, pemberhentian dengan hormat ataupun pemberhentian dengan tidak hormat.

Konsep tanggung jawab menurut Wirjono Prodjodikoro muncul ketika seseorang melakukan perbuatan-perbuatan melawan hukum dalam KUHPerdata ${ }^{11}$. KUHPerdata membedakan tanggung jawab terhadap perbuatan melawan hukum terdiri dari 2 yakni:

1. Tanggung jawab secara langsung didasari oleh Pasal 1365 KUHPerdata berbunyi: "Setiap perbuatan melawan hukum yang oleh karenanya menimbulkan kerugian bagi orang lain, mewajibkan orang yang karena kesalahannya menyebabkan kerugian itu, mengganti kerugian." Notaris harus bertanggunjawab apabila notaris yang bersangkutan melakukan penipuan atau tipu muslihat yang bersumber dari notaris itu sendiri.

2. Tanggung jawab secara tidak langsung didasari oleh Pasal 1367 KUH Perdata berbunyi: "Seseorang tidak hanya bertanggung jawab, atas kerugian yang disebabkan perbuatannya sendiri, melainkan juga atas kerugian yang disebabkan perbuatan-perbuatan orang-orang yang menjadi tanggungannya atau disebabkan barang-barang yang berada di bawah pengawasannya."

Notaris bertanggung jawab atas kelalaian dan kesalahan terhadap isi akta yang dibuatnya. Tanggung jawab tersebut adalah sebagai kesediaannya untuk

\footnotetext{
${ }^{10}$ Dharmawan, N. K. S., Kasih, D. P. D., \& Stiawan, D. (2019). Personal data protection and liability of internet service provider: a comparative approach. International Journal of Electrical and Computer Engineering, 9(4), p. 3177.

${ }^{11}$ Rositawati, D., Utama, I. M. A., \& Kasih, D. P. D. (2017). Penyimpanan Protokol Notaris secara Elektronik dalam Kaitan Cyber Notary. Acta Comitas: Jurnal Hukum Kenotariatan, 2(2), 172-182, h.179-180.
} 
melaksanakan isi kewajibannya yang neliputi kebenaran materiil atas akta yang dibuatnya. Tanggung jawab yang berkaitan dengan kebenaran materiil ialah ${ }^{12}$ :

1. Tanggung jawab Notaris secara Perdata terhadap kebenaran materiil terhadap akta yang dibuatnya. Konstruksi yuridis yang digunakan dalam tanggung jawab perdata terhadap kebenaran materiil terhadap akta yang dibuatnya adalah konstruksi perbuatan melawan hukum.

2. Tanggung jawab Notaris secara Pidana terhadap kebenaraan materiil terhadap akta yang dibuatnya. Mengenai ketentuan pidana tidak diatur di dalam Undang- Undang Jabatan Notaris maupun di dalam Peraturan Jabatan Pejabat Pembuat Akta Tanah, namun tanggung jawab Notaris secara pidana dikenakan jika Notaris tersebut melakukan perbuatan pidana yang melanggar hukum. Undang- Undang Jabatan Notaris hanya mengatur sanksi atas pelanggaran yang dilakukan dan sanksi berupa akta yang dibuat oleh Notaris tidak memiliki kekuatan autentik atau hanya memiliki kekuatan sebagai akta di bawah tangan atau malah akta tersebut dibatalkan secara hukum oleh Pengadilan.

Penjelasan UUJN mengimplikasikan bahwa Notaris bertanggung jawab terhadap kebenaran formalitas suatu akta autentik. Hal ini mensyaratkan bahwa Notaris harus tetap bersifat netral, tidak memihak salah satu pihak, serta memberikan konsultasi atau nasihat hukum kepada semua pihak meminta petunjuk hukum darinya. Berdasarkan hak tersebut, Notaris dapat dipertanggungjawabkan atas kebenaran materiil suatu akta apabila nasihat yang diberikannya ternyata salah atau tidak tepat. ${ }^{13}$

Ketentuan pidana tidak diatur di dalam Undang-Undang Jabatan Notaris, namun seorang Notaris dapat dikenakan tanggung jawab pidana apabila terbukti melakukan perbuatan pidana. Dalam Undang-Undang Jabatan Notaris hanya mengatur sanksi atas pelanggaran yang dilakukan Notaris berupa akta yang dibuatnya. Sedangkan terhadap Notaris sendiri dapat dikenakan sanksi administrasi berupa teguran hingga pemberhentian dengan tidak hormat.

Tindakan hukum yang dilakukan Notaris dalam kewajibannya membuat akta dapat dikenakan pidana, berupa:

1. Membuat surat palsu atau yang dipalsukan dan menggunakan surat palsu yang dipalsukan (Pasal 263 ayat (1) (2) Kitab Undang-Undang Hukum Pidana);

Dalam pasal ini dijelaskan barang siapa membuat surat palsu atau memalsukan surat yang dapat menimbulkan suatu hak, perikatan atau pembebasan utang, atau yang diperuntukkan sebagai bukti daripada sesuatu yang dengan maksud untuk memakai atau menyuruh orang lain memakai surat tersebut seolah-olah isinya benar dan tidak palsu, diancam

12 Anshori, A. G., (2009), Lembaga Kenotariatan Indonesia, Yogyakarta: UII Press, h.16.

13 Tobing, C. I. L. (2019). PERTANGGUNGJAWABAN NOTARIS YANG DIGUGAT ATAS AKTA YANG DIBUAT DENGAN TIDAK ADANYA KESEPAKATAN ANTAR PARA PIHAK (STUDI PUTUSAN NOMOR 73/PDT/2018/PT. DKI). Indonesian Notary, 1(001), h.11. 
jika hal tersebut dapat menimbulkan kerugian karena adanya pemalsuan surat, dengan ancaman pidana paling lama 6 (enam) tahun.

2. Melakukan pemalsuan (Pasal 264 Kitab Undang-Undang Hukum Pidana);

Pasal 264 jo Pasal 264 KUH Pidana berkaitan dengan membuat surat atau akta autentik palsu atau memalsukan akta autentik. Namun tidak memberikan kejelasan mengenai membuat surat palsu, memalsukan surat dan menggunakan surat palsu.

3. Menyuruh mencantumkan keterangan palsu ke dalam akta autentik (Pasal 266 Kitab Undang-Undang Hukum Pidana);

Pasal 266 KUH Pidana berkaitan dengan menyuruh memasukkan keterangan palsu kedalam suatu akta otentik mengenai suatu hal yang kebenarannya harus dinyatakan oleh akta itu, dengan maksud untuk memakai atau menyuruh orang lain memakai akta itu seolah-olah keterangannya sesuai dengan kebenaran, diancam, jika pemakaian itu dapat menimbulkan kerugian, dengan pidana penjara paling lama 7 (tujuh) tahun.

4. Melakukan, Menyuruh melakukan, yang turut serta melakukan (Pasal 55 jo Pasal 263 Ayat (1) (2) atau Pasal 264 atau Pasal 266 Kitab Undang-Undang Hukum Pidana);

5. Membantu membuat surat palsu atau yang dipalsukan dan menggunakan surat palsu atau yang dipalsukan (Pasal 56 Ayat (1) (2) Pasal 263 Ayat (1) (2) atau Pasal 264 Ayat (1) (2) Kitab Undang-Undang Hukum Pidana).

Notaris dapat dikenakan sanksi administratif, perdata maupun pidana terkait dengan akta yang notaris buat. Kerap kali notaris merupakan pihak turut tergugat kecuali apabila akta yang dibuatnya merupakan kesalahan Notaris, pihak yang dirugikan bisa menggugat notaris dan mengajukan permohonan pembatalan akta ke Pengadilan. ${ }^{14}$

Notaris yang lalai dalam melaksanakan tugasnya seringkali menjadi alasan aktanya menjadi cacat secara yuridis yang dapat dikategorikan menjadi 2 yaitu ${ }^{15}$ :

1. Cacat secara formil;

Cacat formil suatu akta telah diatur secara khusus pada Pasal 1869 KUH Perdata yang berbunyi "suatu akta, yang karena tidak berkuasa atau tidak cakapnya pegawai dimaksud di atas, atau karena suatu cacat dalam bentuknya, tidak dapat diperlakukan sebagai akta autentik, namun demikian mempunyai kekuatan sebagai tulisan di bawah tangan jika ia ditandatangani oleh para pihak".

2. Cacat secara materiil

Cacat materiil akta berkaitan dengan syarat sahnya perjanjian sebagaimana diatur dalam Pasal 1320 KUHPerdata yang terdiri dari syarat objektif dan syarat subjektif. Syarat objektif berkenaan dengan objek yang diperjanjikan dan halalnya klausula perjanjian. Apabila syarat

14 Ibid, h.12.

15 Anand, G., \& Hernoko, A. Y. (2016). Upaya Tuntutan Hak Yang Dapat Dilakukan Oleh Pihak Yang Berkepentingan Terhadap Akta Notaris Yang Cacat Yuridis. Perspektif Hukum, 16(2), 154-174, h.156. 
objektif ini dilanggar, maka akta dapat batal demi hukum. Sedangkan syarat subjektif berkaitan dengan kesepakatan para pihak apabila Notaris tidak menuangkan keinginan para pihak atau salah satu pihak ke dalam akta sesuai dengan kesepakatan para pihak, sehingga akta dapat dibatalkan.

Notaris yang bersangkutan dapat dikenai sanksi perdata berupa ganti kerugian dalam hal penggugat merupakan pihak yang dirugikan dari kesalahan notaris. Apabila Notaris terbukti terlibat dalam persekongkolan dan penipuan dalam pembuatan akta, maka Notaris juga dapat dituntut secara pidana ke Pengadilan Negeri. Notaris dapat dikenai sanksi administratif oleh Majelis Pengawas Notaris apabila terjadi pelanggaran kode etik, digugat dan dituntut melalui Kepolisian. ${ }^{16}$

Apabila kemudian dapat dibuktikan bahwa Notaris dengan sengaja memanipulasi data atau menyebabkan hilang maupun rusaknya Akta sehingga memenuhi unsur-unsur perbuatan melawan hukum dalam Pasal 1365 KUH Perdata, maka bentuk tanggung jawab Notaris terdiri dari 3 yaitu administratif, perdata dan pidana. Sanksi administratif atas pelanggaran Pasal 85 UUJN diberikan oleh Majelis Pengawas Pusat, Majelis Pengawas Wilayah, dan Majelis Pengawas Daerah (selanjutnya disebut MPD). Namun MPD sudah menerapkan sanksi administratif berupa teguran lisan terhadap pelanggaran ketentuan cara penyimpanan minuta akta. Lebih lanjut mengenai penyimpanan akta digital belum ditemukan pengaturan spesifik mengenai hal ini. Kedepannya diharapkan adanya pengaturan yang melindungi Notaris beserta keamanan akta nya yang dibuat dan disimpan secara digital. Sanksi yang dapat dikenakan terhadap Notaris membuktikan bahwa Notaris bukanlah suatu profesi atau jabatan yang kebal hukum, melainkan dapat dikenakan sanksi administratif, perdata maupun pidana apabila tidak hati-hati.

\section{Kesimpulan}

Peran Notaris dalam menjaga keamanan akta digital, terutama dalam hal peretasan terhadap perangkat komputernya harus dimulai dari tindakan preventif, seperti meningkatkan keamanan sekuritas perangkat komputer sebagaimana standar kebijakan Resolusi Kongres PBB diatas yang telah dituangkan dalam UU ITE dan PP PSTE. Tanggung jawab Notaris terhadap keamanan akta digital ditentukan apabila kemudian dapat dibuktikan bahwa Notaris dengan sengaja memanipulasi data atau menyebabkan hilang maupun rusaknya Akta sehingga memenuhi unsur perbuatan melawan hukum berdasarkan Pasal 1365 KUHPerdata, maka bentuk tanggung jawab Notaris terdiri dari 3 yaitu administratif, perdata dan pidana. Namun mengenai pelanggaran ketentuan cara penyimpanan minuta akta secara konvensional, Majelis Pengawas Daerah telah menerapkan sanksi administratif berupa teguran lisan. Belum ditemukan pengaturan lebih lanjut mengenai tanggung jawab notaris dalam menjaga keamanan akta yang berbentuk digital, sehingga

${ }^{16} \mathrm{Ibid}$, h.173. 
diharapkan kedepannya peraturan ini dilengkapi dengan tindakan preventif, represif dan sanksi.

\section{Daftar Pustaka}

\section{Buku}

Anshori, A. G., (2009), Lembaga Kenotariatan Indonesia, Yogyakarta: UII Press.

Arief, B. N. (2018). Masalah Penegakan Hukum dan Kebijakan Hukum Pidana dalam Penanggulangan Kejahatan. Jakarta: Prenada Media, h.246-247 dikutip dari United Nations, 1991, Eighth UN Congress on the Prevention of Crime and the Treatment of Offenders, Report.

Mansur, D.M.A.,\& Gultom E. (2009). Cyber Law. Aspek Hukum Teknologi Informasi. Bandung: Refika Aditama.

Nurita, R.A.E. (2012). Cyber Notary Pemahaman Awal Dalam Konsep Pemikiran. Bandung: Refika Aditama.

\section{Jurnal/Skripsi/Tesis}

Arifaid, P. (2017). TanggungJawab Hukum Notaris Terhadap Akta In Originali. Jurnal IUS Kajian Hukum dan Keadilan, 5(3), 510-520.

Anand, G., \& Hernoko, A. Y. (2016). Upaya Tuntutan Hak Yang Dapat Dilakukan Oleh Pihak Yang Berkepentingan Terhadap Akta Notaris Yang Cacat Yuridis. Perspektif Hukum, 16(2), 154-174.

Dharmawan, N. K. S., Kasih, D. P. D., \& Stiawan, D. (2019). Personal data protection and liability of internet service provider: a comparative approach. International Journal of Electrical and Computer Engineering, 9(4), 3175.

Fitriyeni, C. E. (2012). Tanggung Jawab Notaris Terhadap Penyinpanan Minuta Akta Sebagai Bagian Dari Protokol Notaris. KANUN: Jurnal Ilmu Hukum, 14(3), 391-404

Hudzaifah, H. (2015). Keabsahan Tanda Tangan Elektronik Dalam Pembuktian Hukum Acara Perdata Indonesia. Katalogis, 3(5).

Juana, I. K. W. (2019). KEKUATAN HUKUM TANDA TANGAN DIGITAL DALAM PEMBUKTIAN SENGKETA PERDATA MENURUT UNDANGUNDANG NOMOR 11 TAHUN 2008 TENTANG INFORMASI DAN TRANSAKSI ELEKTRONIK. Kerta Dyatmika, 16(1), 62-70.

Putri, C. C., Yahanan, A., \& Trisaka, A. (2019). Penyimpanan Protokol Notaris Secara Elektronik dalam Konsep Cyber Notary (Doctoral dissertation, Sriwijaya University).

Rositawati, D., Utama, I. M. A., \& Kasih, D. P. D. (2017). Penyimpanan Protokol Notaris secara Elektronik dalam Kaitan Cyber Notary. Acta Comitas: Jurnal Hukum Kenotariatan, 2(2), 172-182. 
Rossalina, Z. (2016). Keabsahan Akta Notaris Yang Menggunakan Cyber Notary Sebagai Akta Otentik. Kumpulan Jurnal Mahasiswa Fakultas Hukum.

Setiadewi, K., \& Wijaya, I. M. H. (2020). LEGALITAS AKTA NOTARIS BERBASIS CYBER NOTARY SEBAGAI AKTA OTENTIK. Jurnal Komunikasi Hukum (JKH), 6(1), 126-134.

Tobing, C. I. L. (2019). PERTANGGUNGJAWABAN NOTARIS YANG DIGUGAT ATAS AKTA YANG DIBUAT DENGAN TIDAK ADANYA KESEPAKATAN ANTAR PARA PIHAK (STUDI PUTUSAN NOMOR 73/PDT/2018/PT. DKI). Indonesian Notary, 1(001).

Utami, M. N. (2019). Kejahatan Peretasan (Hacking) dan Pemerasan 3000 Website di 44 Negara Oleh Surabaya Black Hat Dihubungkan Dengan UU No 19 Tahun 2016 Tentang Informasi Teknologi Dan Elektronik (ITE). Skripsi Fakultas Hukum Universitas Pasundan Bandung.

\section{Peraturan Perundang-undangan}

Kitab Undang-Undang Hukum Perdata.

Undang-Undang Republik Indonesia Nomor 2 Tahun 2014 Tentang Perubahan Atas Undang-Undang Nomor 30 Tahun 2004 Tentang Jabatan Notaris.

Undang-Undang Republik Indonesia Nomor 11 Tahun 2008 Tentang Informasi Dan Transaksi Elektronik.

Peraturan Pemerintah Nomor 71 Tahun 2019 tentang Penyelenggaraan Sistem dan Transaksi Elektronik. 